\title{
Growth Medium
}

National Cancer Institute

\section{Source}

National Cancer Institute. Growth Medium. NCI Thesaurus. Code C85504.

A liquid or gel containing nutrients, salts, and other factors formulated to support the growth of microorganisms, cells, or plants. 